\title{
Changes in the structure of bird communities over 10 years in the Ecological Corridor of Paraguay River, Pantanal wetland
}

Studies of bird communities with relation to a river's hydrogeomorphological characteristics associated with its floodplain are important for identifying short and long term spatial-temporal changes. In this perspective, this research aims to evaluate the bird community structure of the Paraguay River through the richness, abundance, composition, diversity and equability indexes over an interval of 10 years, spanning from 2008-2009 to 2018-2019, considering the hydrological periods of flooding, flooded, ebb and drought, as well as sampling the macrohabitats. The study area was developed approaching the Paraguay River hydrology connection in the longitudinal and lateral dimensions. The meandering, rectilinear and transitional functional sectors of the Paraguay River were sampled from the urban areas up to the Descalvados Farm of the municipality of Cáceres, Mato Grosso State, comprising $134 \mathrm{~km}$ of river course with a total of 13 survey areas. Each functional sector, we surveyed a water transect. Also, we surveyed 10 parental bays, with different degrees of lateral connectivity. The survey analyzed and compared two hydrological sampling cycles: the first between June 2008 and March 2009, and the second between August 2018 and April 2019. The sampling protocol consisted of four campaigns corresponding to the hydrological periods of flooding flooded, ebb and drought. The results indicated differences in the community structure and the species composition in the sampled areas between the two cycles. The main change registered between the two cycles was the disappearance of three nests (habitat for feeding and reproduction of colonial birds), which were areas between the two cycles. The main change registered between the two cycles was the disappearance of three nests (habitat for feeding and reproduction of colonial birds), which were
identified in the first cycle and not registered in the second cycle. Mycteria americana (Wood Stork) dominance is highlighted on the nests observed in the first cycle. This species showed up sensitive to environmental changes. The absence of nests in 2018 and 2019, may indicate anthropic changes occurring along the Paraguay river in this time interval. It is our hope that these results will help influence effective decision-making in the diversity conservation of birds in the Paraguay river.

\section{Alterações na estrutura das comunidades de aves em 10 anos, no Corredor Ecológico do rio Paraguai, área úmida Pantanal}

\begin{tabular}{|c|}
\hline $\begin{array}{l}\text { Estudos de comunidades de aves relacionadas com características hidrogeomorfológicas de rios tropicais associados às planícies de inundação são importantes para identificar mudanças } \\
\text { espaço-temporais de curta e longa duração. Nesta perspectiva, esta pesquisa visa avaliar à estrutura da comunidade de aves do rio Paraguai, por meio dos descritores ecológicos riqueza, } \\
\text { abundância, composição, diversidade e equabilidade ao longo de um intervalo de } 10 \text { anos, abrangendo de } 2008-2009 \text { a 2018-2019 e considerando os períodos hidrológicos: enchente, cheia, } \\
\text { vazante e estiagem, bem como amostragem de macrohabitats. O estudo foi desenvolvido abordando a conectividade hidrológica do rio Paraguai nas dimensões longitudinal e lateral. Os } \\
\text { setores funcionais meândrico, retilíneo e de transição do rio Paraguai foram amostrados desde o perímetro urbano até a Fazenda Descalvados no município de Cáceres, Estado de Mato } \\
\text { Grosso, Brasil, compreendendo } 134 \text { km de curso do rio com total de } 13 \text { áreas de amostragem. Em cada setor functional, amostramos um transecto aquático. Também foram amostradas } 10 \\
\text { baías parentais com diferentes graus de conectividade lateral ao longo do rio. Posteriormente, analisamos e comparamos os dois ciclos de amostragem hidrológica: o primeiro entre junho } \\
\text { de } 2008 \text { e março de } 2009 \text {, e o segundo entre agosto de } 2018 \text { e abril de } 2019 \text {. O protocolo de amostragem consistiu em quatro campanhas correspondentes aos períodos hidrológicos de } \\
\text { enchente, cheia, vazante e estiagem. Os resultados indicaram diferenças na estrutura da comunidade e na composição de espécies nas áreas amostradas entre os dois ciclos. A principal } \\
\text { alteração registada entre os dois ciclos foi o desaparecimento de três ninhais (habitat para alimentação e reprodução das aves coloniais), que foram identificados no primeiro ciclo e não } \\
\text { registados no segundo ciclo. A dominância de Mycteria americana (cabeça-seca) é destacada nos ninhais observados no primeiro ciclo. Esta espécie mostrou-se sensível às mudanças } \\
\text { ambientais. A ausência de ninhais no ciclo } 2018-2019 \text {, pode indicar mudanças antrópicas ocorrendo ao longo do rio Paraguai neste intervalo de tempo. Esperamos que esses resultados } \\
\text { ajudem a influenciar a tomada de decisões eficazes na conservação das aves do rio Paraguai. }\end{array}$ \\
\hline
\end{tabular}

Topic: Conservação da Biodiversidade

Reviewed anonymously in the process of blind peer.
Received: 04/03/2021

Approved: 23/03/2021
Rafaella Ferreira Neres de Queiroz (iD) Universidade do Estado de Mato Grosso, Brasil http://lattes.cnpq.br/4407354207664365 http://orcid.org/0000-0003-3731-7346 rafaellaneres83@hotmail.com

\section{Breno Dias Vitorino (D)}

Universidade do Estado de Mato Grosso, Brasil http://lattes.cnpq.br/1051724278201884 http://orcid.org/0000-0002-5293-8581

brenovitorino@gmail.com

Angélica Vilas Boas da Frota (iD

Universidade do Estado de Mato Grosso, Brasil http://lattes.cnpq.br/2392969500908662 http://orcid.org/0000-0003-3693-4756 angelicafrotaa@gmail.com

DOI: 10.6008/CBPC2179-6858.2021.003.0011

\author{
Carolina Joana da Silva (iD) \\ Universidade do Estado de Mato Grosso, Brasil \\ http://lattes.cnpq.br/5253872582067659 \\ http://orcid.org/0000-0003-0517-1661 \\ ecopanta@terra.com.br \\ Solange Kimie Ikeda Castrillon (i) \\ Universidade do Estado de Mato Grosso, Brasil \\ http://lattes.cnpq.br/3373034135331436 \\ http://orcid.org/0000-0003-1862-4615 \\ solangeikeda@unemat.br \\ Josué Ribeiro da Silva Nunes (ib) \\ Universidade do Estado de Mato Grosso, Brasil \\ http://lattes.cnpq.br/3292016056510295 \\ http://orcid.org/0000-0003-3927-5063 \\ joso73@yahoo.com.br
}

Referencing this:

QUEIROZ, R. F. N.; VITORINO, B. D.; FROTA, A. V. B.; SILVA, C. J.; CASTRILLON, S. K. I.; NUNES, J. R. S.. Changes in the structure of bird communities over 10 years in the Ecological Corridor of Paraguay River, Pantanal wetland. Revista Ibero Americana de Ciências Ambientais, v.12, n.3, p.111-125, 2021. DOI: http://doi.org/10.6008/CBPC2179-6858.2021.003.0011 


\section{INTRODUCTION}

Wetlands degradation has occurred at an accelerated rate compared to that of other ecosystems according to the Millennium Ecosystem Assessment (WRI, 2005). Changes in land use, water discharges, natural landscape and environmental structure can influence wetlands functioning, which has significant impacts on river and wetland processes (SILVA et al., 2015). The Ramsar Convention has recognized wetlands with international relevance and established conservation goals for these areas. The United Nations Organization's 2030 Agenda, Objective 15.1, also includes measures for the recovery, conservation and sustainable use of wetlands.

In this context, $1.3 \%$ of the Pantanal wetlands is internationally recognized as a World Heritage Site, and also as a Biosphere Reserve, by UNESCO's Intergovernmental Program - Man and Biosphere (MAB) (AB'SÁBER, 2007; BRASIL, 2015). The Pantanal wetlands also has four conservation units under the status of Ramsar site. Only $4.6 \%$ of the Pantanal is protected by conservation units while wetlands, like the Pantanal, offer global and local ecosystem services, such as the maintenance of microclimates, river recharge, water security, habitat for threatened species and land for migratory species (MITSCH et al., 2015).

The Paraguay River is one of the main tributaries of the Paraguayan Hydrographic Region, which includes the Pantanal. The Paraguay River starts in the Brazilian Central Plateau and travels approximately 2,600 km across this extensive plain (ALMEIDA, 1945) before reaching the Paraná River in Argentina, which, together with its tributaries, is responsible for recharging the Pantanal waters. The Paraguay River system forms an important ecological corridor in South America, presenting geomorphologically distinct zones, a fluvial landscape and the physical structure of aquatic habitats (WANTZEN et al., 2005). Another unique characteristic of this seasonally flooded area is its dependence on the flood pulse, which includes intermittent periods of drought, flooding, flooded and ebb (JUNK et al., 1999).

Due to factors such as the great diversity of birds, the extraordinary abundance of water birds and the formation of large nests, this wetland system is internationally recognized as one of the most important areas in the world for bird watching and research (SICK, 1997; SILVA et al., 2001; TUBELIS et al., 2003). The diversity of natural habitats in the Pantanal offers breeding niches and great feeding options for bird species (SILVA et al., 2001; JUNK et al., 2006; FROTA et al., 2020a), and is important for several migratory species that use its floodplain as reproductive and foraging sites during the rest of continental and intercontinental displacements (SICK, 1997; NUNES et al., 2004; NUNES et al., 2006; FROTA et al., 2020b).

This biological group stands out both for its diversity and adaptation to different environments, as well as for providing important environmental bioindicators (OLIVEIRA, 1995; PRIMACK et al., 2002), as they are sensitive to changes and respond quickly to disturbances in their habitat. They are suitable for assessing and monitoring the ecological consequences of environmental changes (GARDNER et al., 2007). Studies including migratory birds, accidental visitors and introduced species have estimated about 730 species in the region (SILVA et al., 2001). According to Nunes (2011), a total of 582 species can be seen in the Pantanal, corresponding to fourth place in the national bird diversity ranking and including 104 species that directly 
depend on the wetlands (JUNK et al., 2006). Compared to other humid areas, the avifauna occurring in the Pantanal are quite diverse, including the floodplain of the Upper Paraná River with its 295 species (GUIMARAES et al., 2007). And globally, Everglades in Florida, with 365 species (OGDEN, 1969).

Research on the bird community relating to the environmental importance of this fluvial system, as well as its hydrogeomorphological characteristics, will provide significant answers to ecological questions. It is important to note that the conservation of these wetlands can and should be part of a local strategy aimed at reconciling biodiversity conservation with human activity while also respecting their support and resilience (TOMAS et al., 2019). In this context, this research aims to evaluate the bird community structure of the Paraguay River over a 10-year interval, from 2008-2009 to 2018-2019, with consideration to the hydrological cycle periods of flooding, flooded, ebb and drought. Given the advances in use and occupation of this region during this time interval (CALHEIROS et al., 2018), we hope to show changes in the bird community and use this group as an important indicator of environmental changes in this river system for future conservation actions.

\section{METHODOLOGY}

The study area comprised three functional sectors of the Paraguay River: the meandric, rectilinear and transition sectors in the municipality of Cáceres, state of Mato Grosso, Brazil. The sampling design was planned according to the delimitation of these functional sectors by Wantzen et al. (2005). Sampling began in the urban perimeter and extended to the region of Descalvados Farm, totaling $134 \mathrm{~km}$ of river course. In total, 13 areas were sampled, comprising three stretches of river channel and 10 parental bays along the route (Figure 1; Table 1).

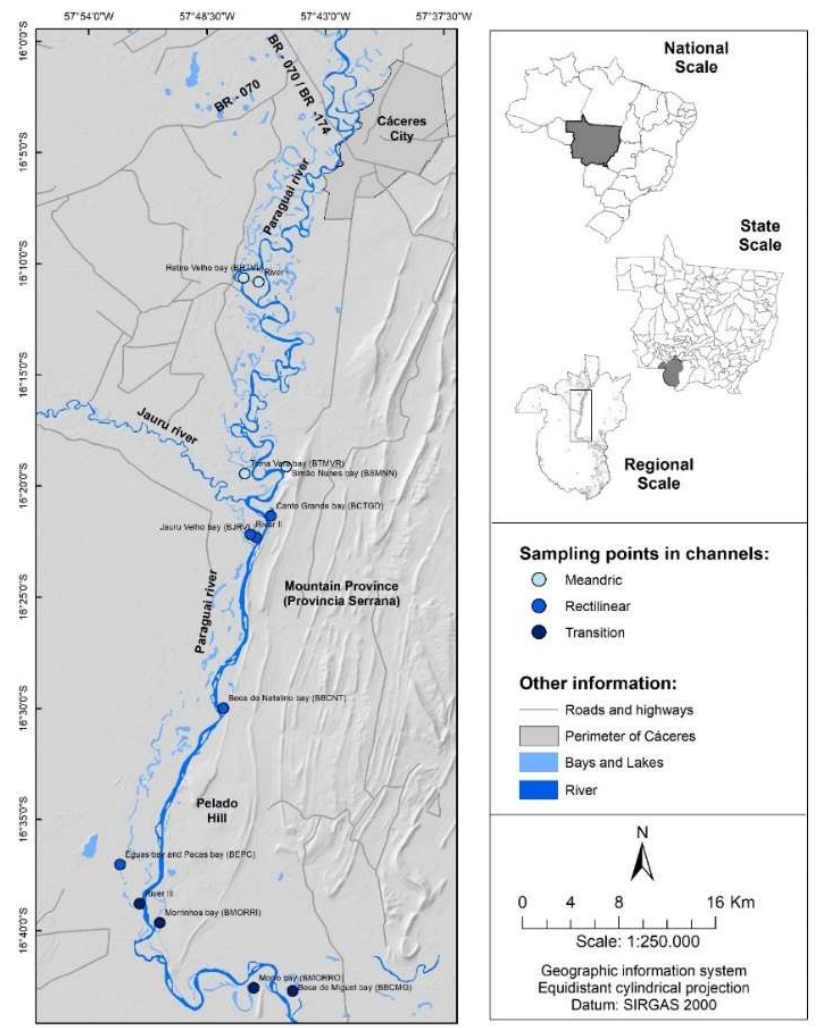

Figure 1: Sampling points and parental bays along the Paraguay River, Pantanal wetland, Mato Grosso, Brazil. 
The two sampling cycles refer to an interval of 10 years: the first between June 2008 and March 2009 and the second between August 2018 and April 2019. The protocol for both samplings consisted of four campaigns corresponding to the hydrological periods of flood, flooded, ebb and drought, as defined by Silva et al. (1995) for research related to the flood pulse in the Pantanal.

The sampling in the different river stretches was carried out from the river, using the transect method (BIBBY et al., 2000) and driving at an average speed of $15 \mathrm{~km} / \mathrm{h}$ over a $5 \mathrm{~km}$ extension in each sector. The bays were sampled using the point count method (BLONDEL et al., 1970), with 3 fixed points of 15 minutes each. All species detected within a 100 m radius were included in the records. Species were identified by a specialist in the field using binoculars, recorders, cameras and, when necessary, the support of specialized literature (GWYNNE et al., 2010). The taxonomic classification followed the Brazilian Ornithological Records Committee (PIACENTINI et al., 2015).

Table 1: Sampling locations on the Paraguay River with extension of sampling areas, connection categories with the parental bays river and geographical coordinates of the points. DPCR: directly and permanently connected to the river; TIR: temporarily isolated from the river; IPCR: indirectly and permanently connected to the river.

\begin{tabular}{|c|c|c|c|c|}
\hline Sampled areas & Extension (km) & Functional Sector & River connection & Geographical coordinates \\
\hline River I & 26,97 & Meandric & & $16^{\circ} 10^{\prime} 52,5^{\prime \prime}$ S $57^{\circ} 46^{\prime} 09,5^{\prime \prime} \mathrm{W}$ \\
\hline River II & 34 & Rectilinear & & $16^{\circ} 22^{\prime} 13,0^{\prime \prime}$ S $57^{\circ} 46^{\prime} 34,7^{\prime \prime} \mathrm{W}$ \\
\hline River III & 30 & Transition & & $16^{\circ} 38^{\prime} 48,6^{\prime \prime} \mathrm{S} 57^{\circ} 51^{\prime} 49,0^{\prime \prime} \mathrm{W}$ \\
\hline Retiro Velho Bay (BRTVL) & 1 & Meandric & DPCR & $16^{\circ} 10^{\prime} 40,7^{\prime \prime}$ S $57^{\circ} 46^{\prime} 51,6^{\prime \prime} \mathrm{W}$ \\
\hline Toma Vara Bay (BTMVR) & 1,5 & Meandric & TIR & $16^{\circ} 19^{\prime} 29,3^{\prime \prime}$ S $57^{\circ} 46^{\prime} 49,8^{\prime \prime} \mathrm{W}$ \\
\hline Simão Nunes Bay (BSMNN) & 1,5 & Meandric & DPCR & $16^{\circ} 19^{\prime} 10,8^{\prime \prime}$ S $57^{\circ} 44^{\prime} 54,3^{\prime \prime} \mathrm{W}$ \\
\hline Canto Grande Bay (BCTGD) & 1,5 & Rectilinear & DPCR & $16^{\circ} 21^{\prime} 23,5^{\prime \prime}$ S $57^{\circ} 45^{\prime} 37,9^{\prime \prime} \mathrm{W}$ \\
\hline Jauru Velho Bay (BJRVL) & 2,2 & Rectilinear & IPCR & $16^{\circ} 22^{\prime} 20,8^{\prime \prime} \mathrm{S} 57^{\circ} 46^{\prime} 19,6^{\prime \prime} \mathrm{W}$ \\
\hline Boca do Natalino Bay (BBCNT) & 1,5 & Rectilinear & DPCR & $16^{\circ} 30^{\prime} 01,7^{\prime \prime} \mathrm{S} 57^{\circ} 47^{\prime} 52,3^{\prime \prime} \mathrm{W}$ \\
\hline Éguas e Pacas Bay (BEPC) & 4 & Rectilinear & IPCR & $16^{\circ} 38^{\prime} 05,6^{\prime \prime} \mathrm{S} 57^{\circ} 62^{\prime} 01,9^{\prime \prime} \mathrm{W}$ \\
\hline Morrinhos Bay (BMORRI) & 3 & Transition & IPCR & $16^{\circ} 39^{\prime} 40,5^{\prime \prime} \mathrm{S} 57^{\circ} 50^{\prime} 52,6^{\prime \prime} \mathrm{W}$ \\
\hline Morro Bay (BMORRO) & 2 & Transition & IPCR & $16^{\circ} 42^{\prime} 37,2^{\prime \prime} \mathrm{S} 57^{\circ} 46^{\prime} 30,5^{\prime \prime} \mathrm{W}$ \\
\hline Boca do Miguel Bay (BBCMG) & 6 & Transition & IPCR & $16^{\circ} 42^{\prime} 45,7^{\prime \prime} \mathrm{S} 57^{\circ} 44^{\prime} 42,1^{\prime \prime} \mathrm{W}$ \\
\hline
\end{tabular}

In the data analysis, the richness estimate for the sampled areas was verified by the first and secondorder Jackknife estimator using the EstimateS software (COLWELL, 2013). The ranked abundance curve (Whittaker Plot) was used to show the species relative abundance, with uniformity reflected in the slope of the line in the graph. A steep slope indicates low uniformity in the species distribution in the community, as species at the top of the line in the graph represent a higher abundance than species present at the base (WHITTAKER, 1965).

The Mann-Whitney's test was used to assess whether there was a difference between the richness and abundance (response variables) in the sampled years (predictor variables). The Kruskal-Wallis test was used to verify the difference in bird's richness and abundance (response variables) in the different hydrological cycles (predictor variables). For the significant results, post hoc Dunn test was applied in order to pairwise test for multiple comparisons of mean rank sums.

The Shannon-Weaner diversity index $\left(\mathrm{H}^{\prime}\right)$ was applied to visualize the sampled areas species diversity (KREBS, 1989), while the Pielou Equability Index (PIELOU, 1975) was used to compute the individual's distribution uniformity among existing species and the Jaccard Similarity Index was used to verify the proportion of species shared between the sampled areas. The analyzes were performed using $R$ software ( $R$ 
CORE TEAM, 2019) with the vegan package (OKSANEN et al., 2019).

\section{RESULTS}

During sampling in the 2008-2009 campaign, 21,142 individuals were registered, belonging to 220 species of birds distributed in 56 families and 22 orders. In the 2018-2019 campaign, 6,680 individuals belonging to 176 species of birds distributed in 55 families and 25 orders were registered (Figure 2). Among the 56 families registered in 2008-2009, taking richness into consideration, the most representative families were Tyrannidae $(n=20)$ followed by Ardeidae and Psittacidae $(n=14)$ (Figure 2$)$.

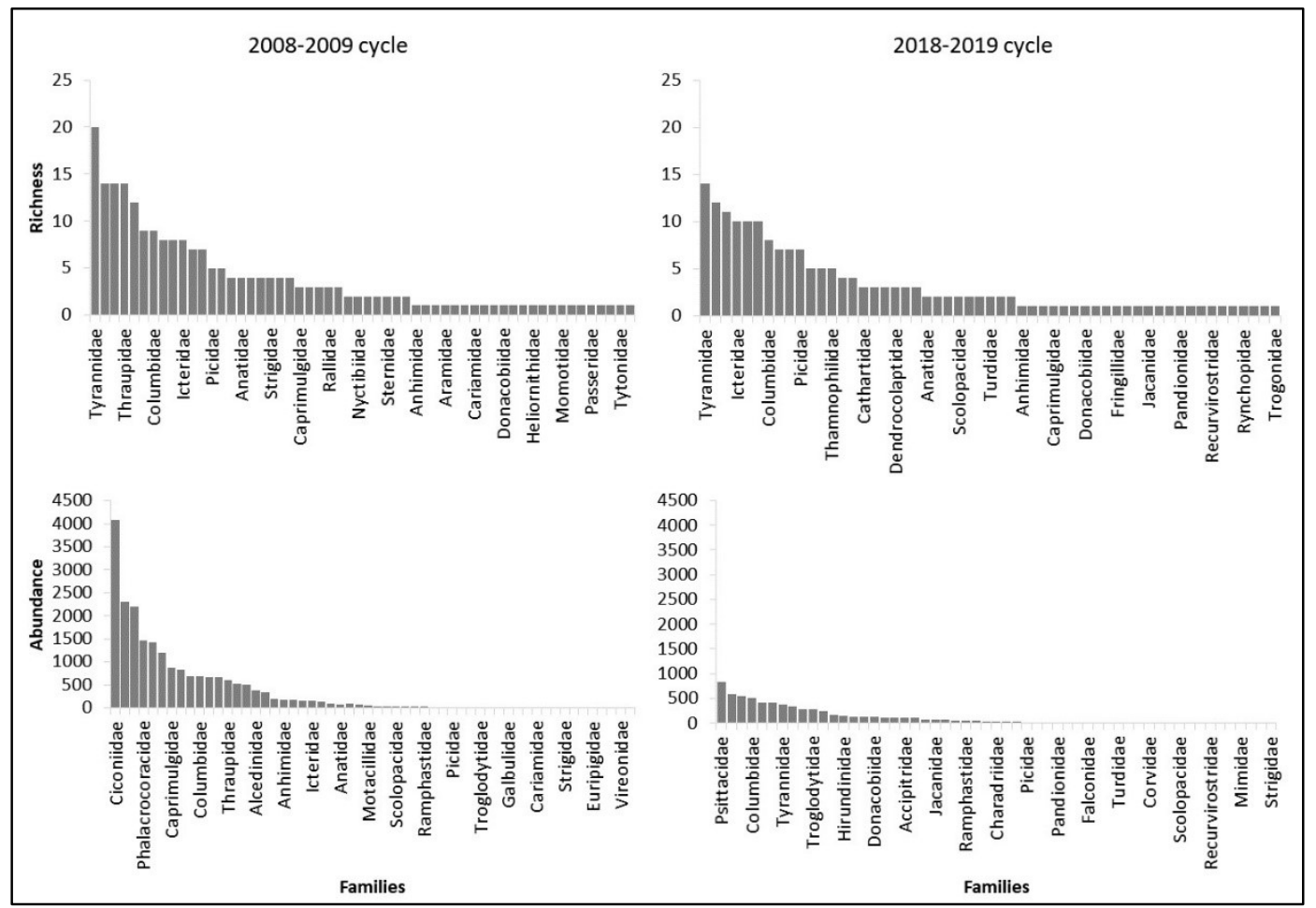

Figure 2: Richness and abundance of bird species per family, recorded in the 2008-2009 and 2018-2019 cycles along the Paraguay River and parental bays, Pantanal wetland, Mato Grosso, Brazil.

Among those registered between 2018-2019, the families Tyrannidae $(n=14)$, Psittacidae $(n=12)$ and Ardeidae ( $n=11)$ (Figure 2 ) were the most representative. The most abundant families registered in the 2008-2009 campaign were Ciconiidae $(n=4,092)$, followed by Ardeidae $(n=2,297)$ and Hirundinidae $(n=$ $2,192)$ (Figure 2). For the 2018-2019 cycle, the Psittacidae family $(n=840)$ stood out, followed by Phalacrocoracidae $(n=588)$ and Ardeidae $(n=574)$ (Figure 2).

When assessing sample sufficiency, it is noted that the richness observed in the field represented $70 \%$ of the total richness estimated by the first order ( 314 spp.) and 59\% by the second-order jackknife ( 357 spp.) for 2008-2009 (Figure 3). The observed richness for 2018-2019 represented $78 \%$ of the total richness estimated by the first order ( 225 spp.) and $68 \%$ by the second-order jackknife ( $259 \mathrm{spp}$.) (Figure 3 ). The estimators indicated that the richness may be greater than that found for the two cycles, but the curves tend to stabilize, not yet reaching the asymptote. 


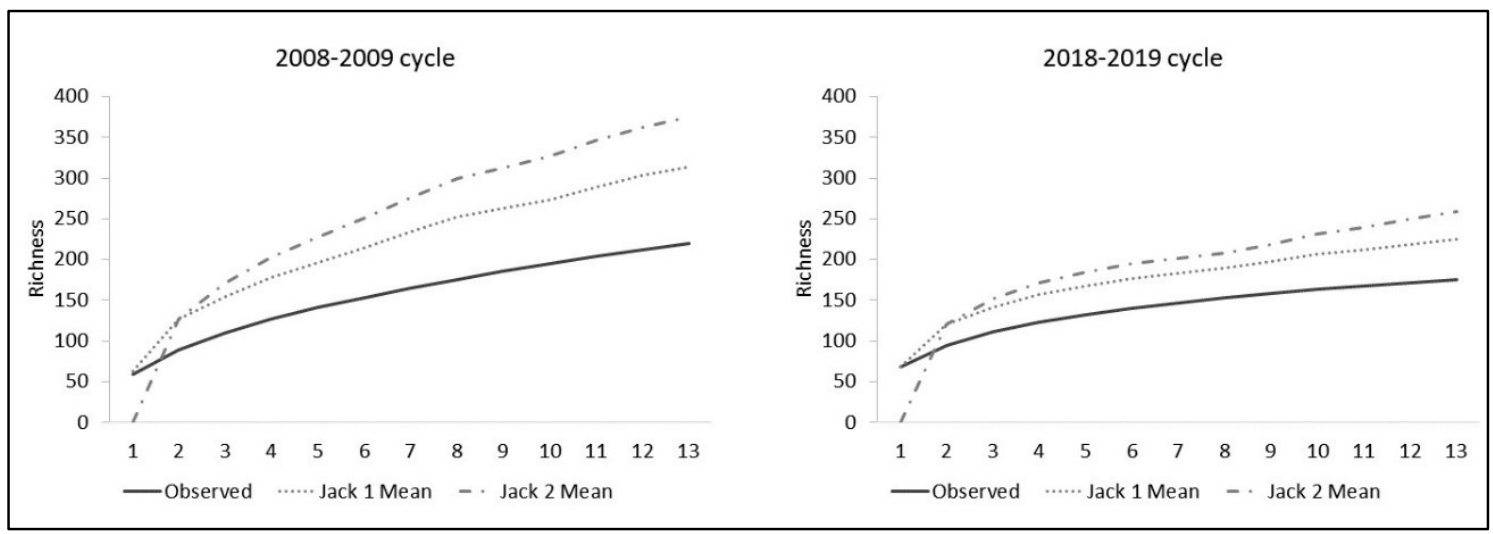

Figure 3: Cumulative curve of species (observed) and estimated richness according to first and second-order jackknife estimator for the bird community registered in the 2008-2009 and 2018-2019 cycles in 13 sampling areas along the Paraguay river and parental bays, Pantanal wetland, Mato Grosso, Brazil.

The most abundant species in the 2008-2009 cycle were Mycteria americana (Wood Stork) ( $n=4,054$ individuals; relative abundance $(R A)=0.19)$, Nannopterun brasilianus (Neotropic Cormorant) $(n=1,472 ; R A$ $=0.07)$ and Progne chalybea (Gray-breasted Martin) $(n=1,299 ; R A=0.06)$. Regarding the sample areas and hydrological periods, M. americana had distribution in all bays and river sections but was more abundant in the transitional sector in the drought and ebb periods. The species $N$. brasilianus occurred in the bays and sectors of the river and all hydrological periods. P. chalybea had a distribution only in the river sectors in ebb and drought periods.

Regarding the 2018-2019 cycle, N. brasilianus stood out ( $n=588$; RA = 0.09), along with Brotogeris chiriri (Yellow-chevroned Parakeet) $(n=427 ; R A=0.06)$ and Pitangus sulphuratus (Great Kiskadee) $(n=262$; RA $=0.04)$. We highlight that $P$. sulphuratus were distributed in all periods in bays and stretches of the river. The relative abundance curve showed that the dominant species in the 2008-2009 cycle was M. americana, followed Nannopterum brasilianus (Figure 4). The steep slope of the curve indicates low uniformity in the distribution of species in this cycle. The relative abundance curve for 2018-2019 showed that N. brasilianus dominated (Figure 4), with greater uniformity in the distribution of species in this period indicated by a less pronounced slope.

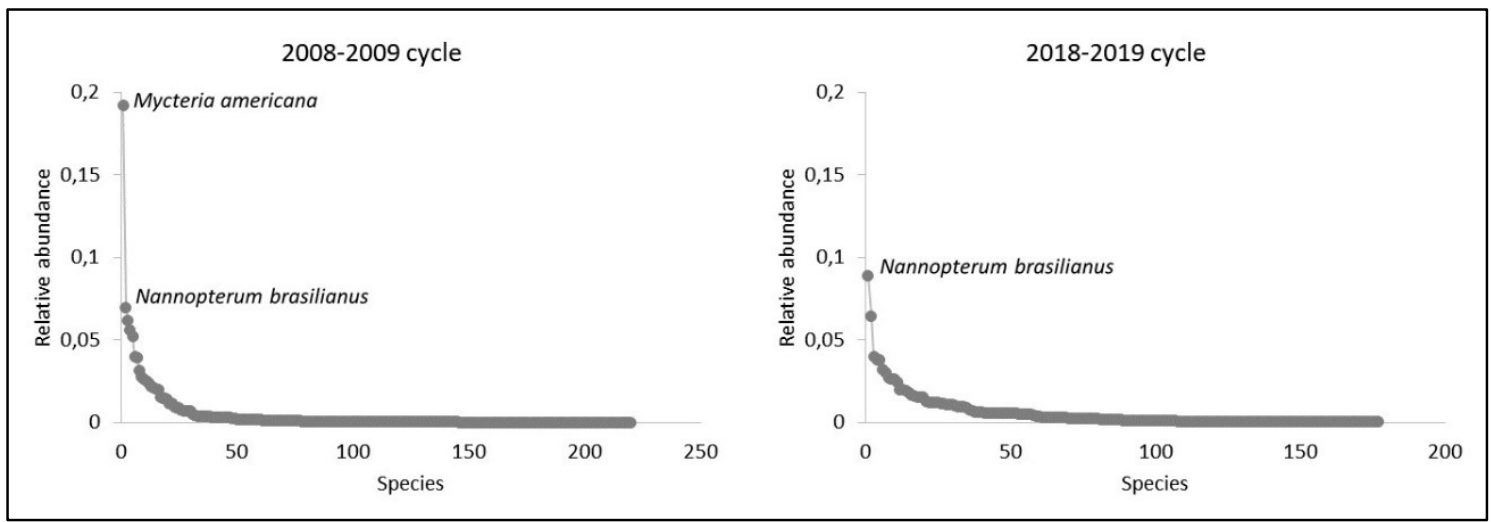

Figure 4: Abundance curves (Whittaker plots) for bird species recorded in the 2008-2009 and 2018-2019 cycles at all sampling points along the Paraguay River and parental bays, Pantanal, Mato Grosso, Brazil.

The Mann-Whitney test showed that there was no significant difference between the sampled cycles richness ( $\mathrm{W}=1311.5 ; \mathrm{p}=0.79)$. However, abundance was different between the cycles, being significantly 
higher in the 2008-2009 and 2018-2019 cycle ( $W=2017 ; p<0.001)$ (Figure 5). When assessing abundance according to hydrological periods (flooding, flooded, ebb and drought) between the 2008-2009 and 20182019 cycles, significant differences were noted in the periods of ebb and drought ( $W=160 ; p<0.001$ and $W$ $=132 ; p=0.01$, respectively), both being higher in the 2008-2009 cycle. In terms of species richness in the different periods of the sampled cycles, there were no significant differences.

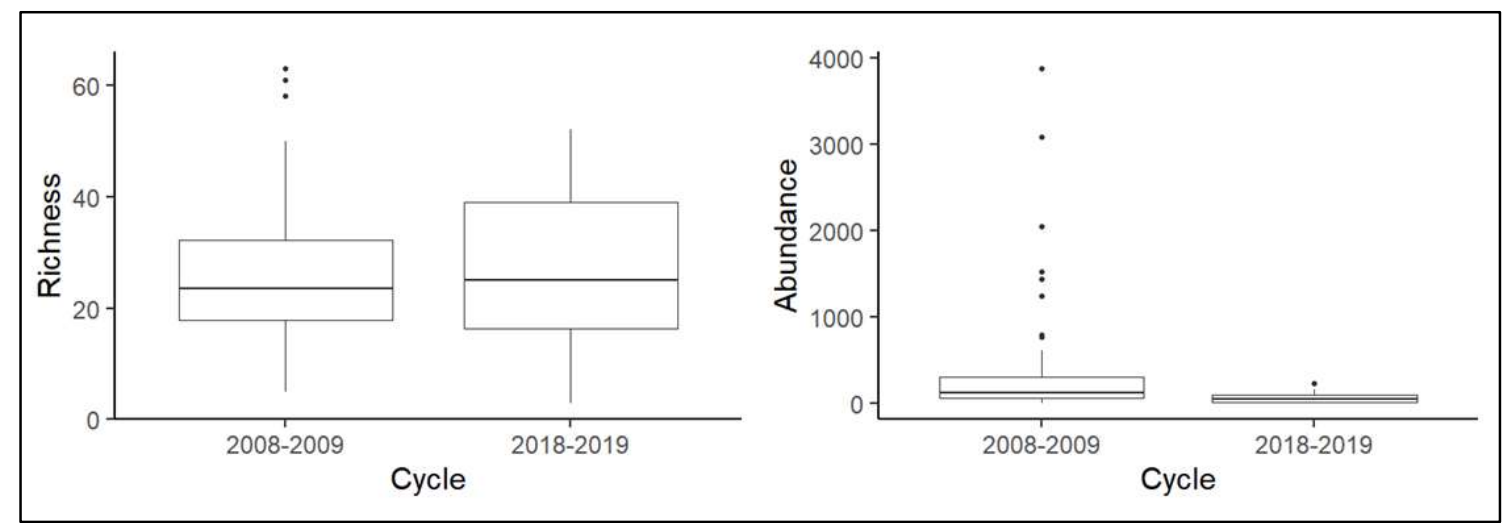

Figure 5: Richness and abundance of bird species between the 2008-2009 and 2018-2019 cycle sampled in the Paraguay River, Pantanal wetland, Mato Grosso, Brazil.

The richness and abundance sampled in the 2008-2009 cycle were both different between the hydrological periods $\left(X^{2}=14.32, p<0.01 ; X^{2}=11.68, p<0.01\right.$, respectively) (Figure 6). The post hoc Dunn test indicated that the richness was different between periods the drought-flooded ( $p$ adjusted $<0.01$ ), ebbflooded ( $p$ adjusted $<0.05$ ) and drought-flooding ( $p$ adjusted $=0.05$ ). Abundance was different between periods the drought-flooded ( $p$ adjusted $<0.05$ ) and ebb-flooded ( $p$ adjusted $<0.05$ ) periods in 2008-2009. There were no significant differences in richness and abundance between the hydrological periods of the 2018-2019 cycle (Figure 6).

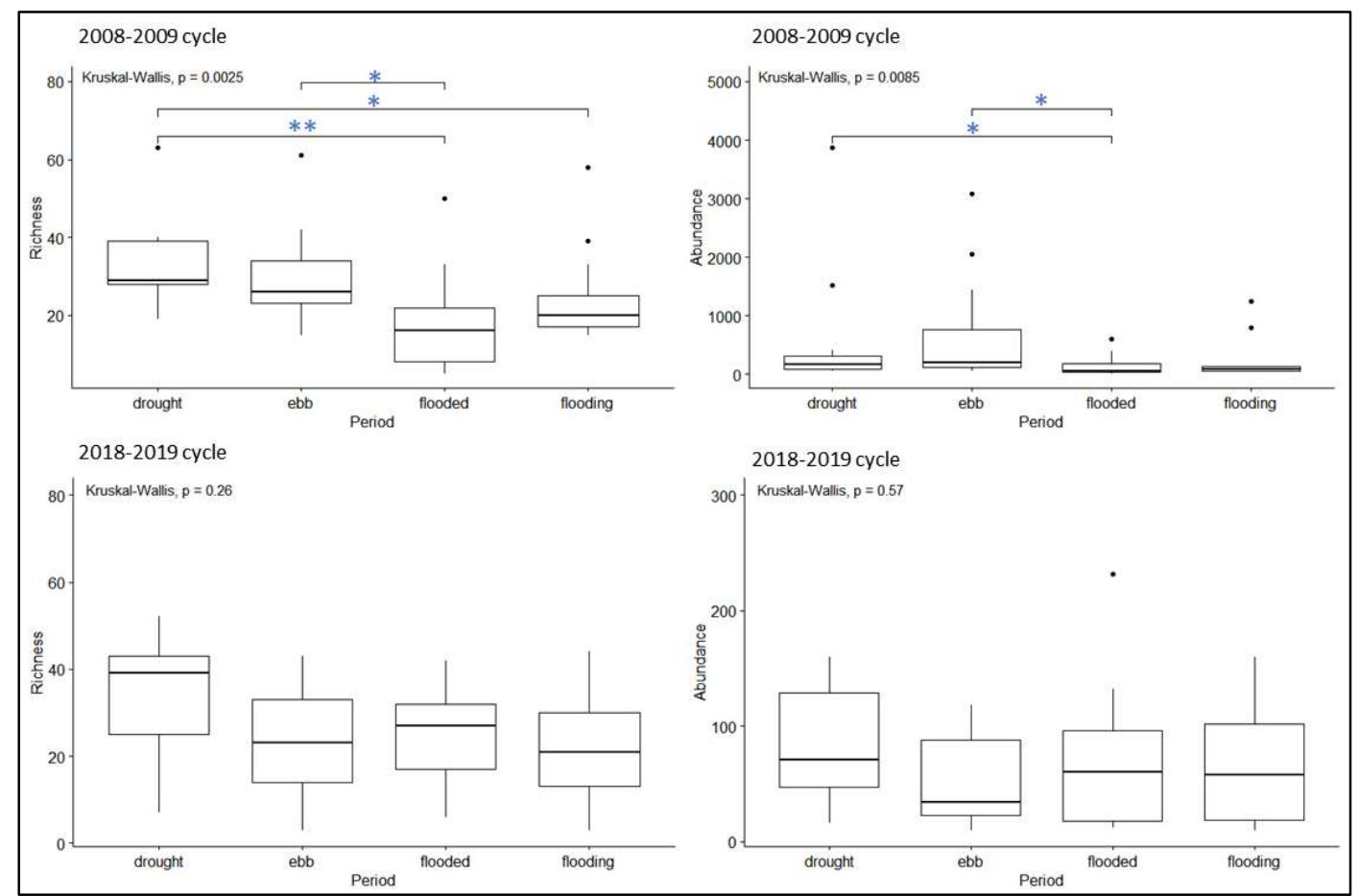

Figure 6: Richness and abundance of bird species in the 2008-2009 and 2018-2019 cycle for the hydrological periods of drought, ebb, flooding and flooded sampled in the Paraguay River, Pantanal wetland, Mato Grosso, Brazil. 
Considering this relationship between the bird community and the sampled areas, the Shannon Diversity Index ranged from $\mathrm{H}^{\prime}=1.96$ (BTMVR) to $\mathrm{H}^{\prime}=3.54$ (BBCMG) for 2008-2009, and $\mathrm{H}^{\prime}=2.75$ (BEPC) to $\mathrm{H}^{\prime}=3.91$ (BCTGD) for 2018-2019. For the Pielou's Equability index, the variation was from J = 0.50 (BTMVR) to $\mathrm{J}=0.89(\mathrm{BJRVL})$ for 2008-2009, and from $\mathrm{J}=0.65(\mathrm{BEPC})$ to $\mathrm{J}=0.90$ (BCTGD) for 2018-2019 (Table 2).

Table 2: Richness and diversity index (Shanon-Weaner) and Pielou equitability $(\mathrm{J})$ of the bird community sampled along the Paraguay River and parental bays, Pantanal wetland, Mato Grosso, Brazil.

\begin{tabular}{|c|c|c|c|c|c|c|}
\hline \multirow{2}{*}{ Diversity } & \multicolumn{2}{|l|}{ Richness (S) } & \multicolumn{2}{|c|}{ Shannon-Weaner (H') } & \multicolumn{2}{|c|}{ Equability (J) } \\
\hline & $2008 / 2009$ & $2018 / 2019$ & $2008 / 2009$ & $2018 / 2019$ & $2008 / 2009$ & $2018 / 2019$ \\
\hline River I & 92 & 50 & 3.09 & 3.10 & 0.68 & 0.79 \\
\hline River II & 52 & 60 & 3.11 & 3.43 & 0.79 & 0.84 \\
\hline River III & 117 & 60 & 2.86 & 3.25 & 0.60 & 0.79 \\
\hline BRTVL & 39 & 68 & 3.07 & 3.71 & 0.84 & 0.88 \\
\hline BTMVR & 49 & 75 & 1.96 & 3.60 & 0.50 & 0.83 \\
\hline BSMNN & 52 & 76 & 3.48 & 3.70 & 0.88 & 0.85 \\
\hline BJRVL & 32 & 71 & 3.07 & 3.64 & 0.89 & 0.85 \\
\hline BBCNT & 54 & 77 & 3.44 & 3.69 & 0.86 & 0.85 \\
\hline BCTGD & 46 & 76 & 3.14 & 3.91 & 0.82 & 0.90 \\
\hline BEPC & 49 & 68 & 2.07 & 2.75 & 0.53 & 0.65 \\
\hline BMORRI & 58 & 89 & 3.46 & 3.81 & 0.85 & 0.85 \\
\hline BMORRO & 53 & 81 & 3.39 & 3.76 & 0.85 & 0.85 \\
\hline BBCMG & 67 & 42 & 3.54 & 2.97 & 0.84 & 0.79 \\
\hline
\end{tabular}

Based on Jaccard's similarity, the clusters differ between studied cycles (Figure 8). For the 2008-2009 cycle, an average similarity of 0.25 was observed with a cluster consisting of two stretches of the river (R1 meandering sector, R3 transition sector) and another grouping composed of the other areas. In the 20182019 cycle, the average similarity was 0.31 and a change occurred in the structure of the clusters, in which the stretches of the river (R1, R2 and R3) were more similar to BMORR and BBCMG Bay (transition sector).

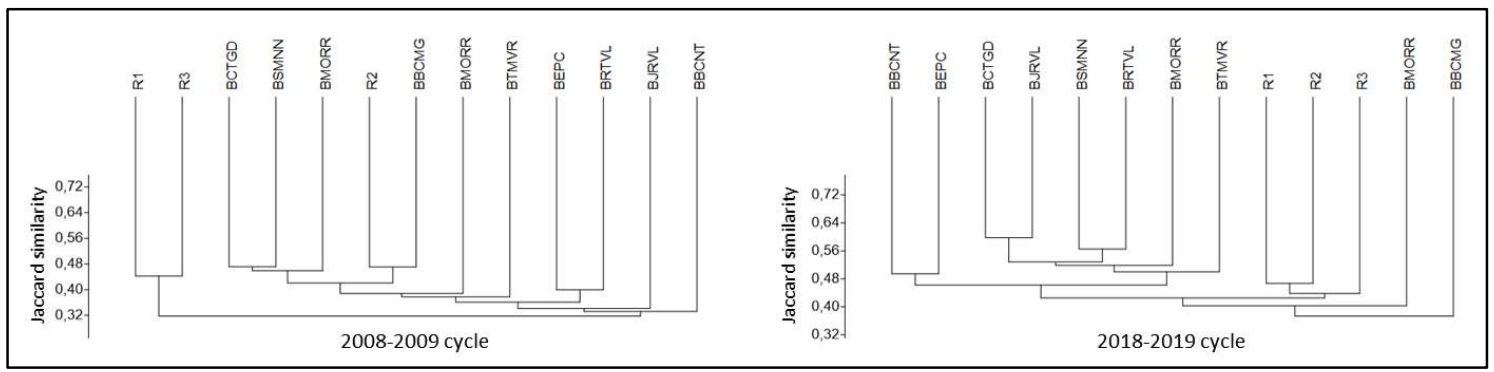

Figure 8: Jaccard similarity dendrogram of the bird community in the 2008-2009 and 2018-2019 cycles from the sampled areas along the Paraguay river and parental bays, Pantanal wetland, Mato Grosso, Brazil.

\section{DISCUSSION}

\section{Species richness, abundance and composition}

The species richness was not different between the cycles sampled in the Paraguay River, however, we found differences between abundances and composition. The high number of species in this environment is already expected since it is in floodplain. Similar records were observed in other floodplains by Nunes (2011) and Barcellos (2006), in Mato Grosso do Sul and the Rio Grande do Sul, respectively. Although the richness is similar in the two sampled cycles, the 2008-2009 cycle showed greater abundance than the 20182019 cycle. This 10-year interval denotes a decline in species abundance in different environments. One of the changes observed in the field was the absence of large nests from the 2018-2019 cycle that once existed 
in the sampled area, leading to a decreased abundance of registered birds in the 2018-2019 cycle.

Nests are colonies for aquatic birds built on shrubs located in humid areas (SICK, 1997). Nests can form by anhinga (black nests), or by herons, spoonbills and wood storks (white nests) (YAMASHITA et al., 1990; SILVA et al., 2000). Studies focusing on nests in the Pantanal of Mato Grosso were carried out in the Corutuba (Barão do Melgaço, Mato Grosso), including one of the largest nests in the Pantanal. The environmental characterization of this nest by Bouton (1999) and Silva et al. (2000) reported human disturbances on the reproductive success of wood storks.

In the 2008-2009 cycle, three large nests were present, however, there was no monitoring and information about the nests in the Paraguay River after 2009, and their absence in subsequent years may indicate anthropogenic effects on the aquatic birds nesting in this area. Another factor that explains the absence of the nests was the fire in the Pantanal. In 2009, there was a major forest fire in the region of the largest nest identified in the 2008-2009 study, which was in the transition sector. According to data from the National Institute for Space Research (INPE), the Pantanal had 5,037 fires in 2009.

The families Tyrannidae, Ardeidae and Psittacidae were richer in the two sampled cycles. In terms of abundance, the same pattern did not occur, with the Ciconiidae family being the most abundant in the 20082009 cycle and the Psittacidae family being the most abundant in the 2018-2019 cycle. The wide distribution of species belonging to these families favored registration in the sampled cycles. The Tyrannidae (Passeriformes) family is exclusively neotropical and has the greatest species richness among all groups of birds in this region (GILL, 1994). The Ardeidae (herons) and Psittacidae (macaws, parakeets, parrots) families, on the other hand, have a wider distribution, prevailing in tropical and temperate regions (MARTíNEZVILALTA et al., 1992; COLLAR, 1997; SICK, 1997). In addition, they are birds that usually live in flocks.

The species of the Ciconiidae family (storks) are represented by medium to large swamp birds in a cosmopolitan distribution (WINKLER et al., 2020). Despite having high richness, $40 \%$ of the species belonging to the family are included in the Red List of threatened species. However, all species of this family are indirectly in danger, considering the acceleration of the degradation of flooded areas where these species forage and reproduce (International Union for Conservation of Nature and Natural Resources - IUCN). Among the Ciconiidae species in the Paraguay River, Ciconia maguari (maguari stork), Jabiru mycteria (Jabiru) and M. americana (Wood Stork) were registered. The species Anodorhynchus hyacinthinus (Hyacinth Macaw) and Penelope ochrogaster (Chestnut-bellied Guan) were also registered in the study and are threatened in a vulnerable category.

In the 2008-2009 sampling, there was a high dominance of the species M. americana (Wood stork), as shown by the species dominance curve. Mycteria americana is the second largest species of the family Ciconiidae in the Neotropical region, this species is distributed from the southeastern United States to the northern region of Argentina (SICK, 1997). The presence of nests at river 1, 3 and Éguas e Pacas Bay (BEPC) contributed to the greater expressiveness of $M$. americana in the 2008-2009 cycle. The abundance of $M$. americana varied from 4,054 individuals in the 2008-2009 sampling to 42 individuals in 2018-2019. This denotes a significant change in the environment along the Paraguay River, as M. americana is a very sensitive 
species to environmental changes.

Among the characteristics of the migratory aquatic species occurring in the Pantanal (NUNES et al., 2004), the formation of colonies stands out, as large populations are found in the Pantanal region in the reproductive period (July and November) and flocks are found in the post-reproductive period (SICK, 1997). The population reduction of M. americana in South Florida between 1930 and 1978 has been attributed to deforestation, pollution and water level manipulation (OGDEN et al., 1987; MITCHELL, 1999), and, since 1984, the species has been listed as endangered under US domestic law (U. S. FISH AND WILDLIFE SERVICE., 2004). There are no systematic censuses of this species in the Brazilian Pantanal region (LOPES, 2006) and this work reports the drastic population decline of the species in the Paraguay River.

However, in the 2018-2019 cycle, with the decrease of abundance of M. americana, Nannopterum brasilianus became the most representative species. In sequence, Pitangus sulphuratus was one of the dominant species. This is one of the most common species in Brazil, occurring in several types of environments including urban ones (SIGRIST, 2006). Being a generalist species, $P$. sulphuratus presents plasticity to the impacts of human activities on landscapes, in addition to having a high capacity for adapting to altered environments (SICK, 1997). Human interventions significantly affect bird species inhabiting natural ecosystems (MARINI et al., 2005). Our results indicated possible anthropogenic disturbances in the Paraguay River, evidenced by the absence of nests and a decrease in species abundance, as well as changes in the composition of the bird community.

\section{Environmental variation and hydrological periods}

Species diversity is one attribute that makes it possible to evaluate an environment (MAGURRAN, 2004), alongside the dynamics, niche heterogeneity (WIINEMILLER et al., 2000), dimension of the vegetation cover (KINGSFORD et al., 2004; NUNES, 2005; CONNOR et al., 2006), floristic composition, food availability (HOLMES, 1990) and the complexity of the flooding environment (FAIRBAIN et al., 2001). These factors can influence the richness as well as the abundance and composition of avifauna in the wetlands. Even, the size of the floodable area also represents an essential factor in the maintenance of bird richness, since the inundation area and the inundation period dictate the availability of habitat and food and, thus, condition the bird abundance and the reproductive period (HERZOG et al., 2002; AZERIA, 2004; RUSSEL et al., 2006; BONETTO et al., 1981).

Such factors may have led to changes in the structure and size of these environments during the time interval, highlighting the connectivity between these environments and its influence on species distribution patterns. In the 2018-2019 cycle, river 1, 2 and 3 had greater similarity compared to the 2008-2009 cycle. This denotes the importance of marginal bays in maintaining species in the river. Lateral flooding is decisive in the Pantanal environment in terms of connectivity between rivers and adjacent bays (JUNK et al., 1989), and is also of fundamental importance for birds that inhabit aquatic and terrestrial transition zones (FROTA et al., 2020a).

Seasonal variations in the environment that species are subjected to also directly influences the 
structure and composition of communities (THOMAS et al., 2020). The richness and abundance of birds varied according to the hydrological periods only in the 2008-2009 cycle. During the drought periods, greater richness and abundance of birds were sampled than in the flooded periods in the Paraguay River for the first hydrological cycle. This pattern is common in the region mainly due to the relationship of migratory species seeking this region during these hydrological periods to forage and reproduce (OLIVEIRA et al., 2016). The decrease in the water level in these periods favors the concentration of fish, the main food base of most aquatic birds. For the second cycle, we found no significant differences, and this is very worrying. The loss of water mass in recent years has changed this landscape (LÁZARO et al. 2020), and this may be directly affecting the dynamics of the bird community.

In a study carried out in Rio Sinos, in the southern region of Brazil, there was no significant difference neither in terms of richness nor in terms of bird abundance between the rainy and dry seasons (PETRY et al., 2008). As for pond environments in the state of Minas Gerais, an increase in bird abundance was observed in the dry season, however, the estimated species richness did not differ between seasons (RODRIGUES et al., 2005), findings that corroborate with this study. Thus, differing from the fluvial-lacustrine sector of the Paraguay River, where no difference was found in the richness and abundance between the periods, but for the composition of bird species (FROTA et al., 2020a).

In short, the main threats to bird communities are due to human activities. Silva et al. (2015) evidenced agriculture and energy as the main drivers effecting the region with the pressures of hydroelectric development and deforestation. The authors also observed the conversion of natural ecosystems to commodity agroecosystems, Cerrado's vegetation fragmentation and rivers in their longitudinal hydrological dimension. Findings by Calheiros et al. (2018) corroborate with these studies, highlighting the hydrological regime alteration and its potential impact on the flood pulse through hydroelectric projects; 169 dams exist between current and planned projects, with a growth of more than $500 \%$ in the last 15 years, $86 \%$ of which are small hydroelectric plants.

The implantation of three grain shipping ports is resuming on the Paraguay River in the municipality of Cáceres, part of the Paraguay Paraná Waterway project that was planned in the 1990s and then abandoned under pressure from civil society coordinated by the Rios Vivos Coalition. Studies developed at the time show inconsistencies of the proposal in the main river, with severe impacts on hydrology, ecology and biodiversity for a vulnerable system such as the Pantanal (WANTZEN et al., 1999; HAMILTON, 1999; SCHULZ et al., 2017).

These driving forces place bird communities at risk, especially the aquatic species that define the indication of Ramsar sites, such as the Taiamã Ecological Station and the Pantanal Mato-Grossense National Park, the conservation of the National Patrimony (defined in the 1988 constitution), the World Patrimony and Biosphere Reserve and the Pantanal of Mato Grosso, which has local and global importance. The Wetlands International (2005) confirms that increasing degradation of flooded areas through pollution, drainage and abuse of water extraction has led to loss of this ecological system. The imbalance in the flood pulse and the loss of marked differences between flooded, ebb, drought and flooding periods, decrease in the amount of rain, and the loss of water mass in the landscape over the last 10 years specifically in during 
the drought season in the Paraguay river (LÁZARO et al. 2020) lead to an imbalance of the environment and maintenance of associated species. M. americana in the United States as an example, leads to the abandonment of the reproductive colonies (MITCHELL, 1999). Similar changes as those occurring in that evaluated river system may justify the decline of the same species in the Paraguay River over 10 years.

\section{CONCLUSIONS}

The results pointed to a distinction in the community structure between the two cycles (2008-2009 and 2018-2019) showing a difference in relative abundance and the composition of species in the environment. The presence of nests registered in the 2008-2009 cycle indicated the dominance of $M$. americana, a sensitive species to environmental changes. The absence of nests in the 2018-2019 cycle, may indicate anthropic changes that have occurred along the Paraguay River in this time interval. It is hoped that the results of this comparison can influence effective decision-making for the conservation of the Paraguay River, as well as subsidize management strategies in the ecological corridor and conservation units in the area, in combination with social groups and decision-makers.

ACKNOWLEDGEMENTS: We thank the Graduate Program in Environmental Sciences (PPGCA), the Coordination for the Improvement of Higher Education Personnel - CAPES, through the granting of a scholarship to RFNQ, BDV and AVBF, and also the Ecological and Economic Corridor Project of the Paraguay River (CORE), financed by FAPEMAT context of climate change, biological group Avifauna, in which this research is inserted.

\section{REFERENCES}

AB'SABER, A. N.. Os domínios de natureza no Brasil: potencialidades paisagísticas. 4 ed. São Paulo: Ateliê, 2007.

ACCORDI, I. A.; BARCELLOS, A.. Composição da avifauna em oito áreas úmidas de Bacia Hidrografica do Lago Guaíba, Rio Grande Sul. Revista Brasileira de Ornitologia, v.14, n.2, p.101-115, 2006.

ALMEIDA, F. F. M.. Geologia do Sudoeste Matogrossense. Boletim da divisão de Geologia e Mineralogia, Rio de Janeiro, v.116, p.19-25, 1945

AZERIA, E. T.. Terrestrial bird community patterns on the coralline islands of the Dahlak Archipelago, Red Sea, Eritrea. Global Ecology and Biogeography, v.13, p 170-187, 2004.

BIBBY, C. J.; JONES, M.; MARSDEN, S.. Bird Surveys (Expedition Field Techniques Series). Bird Life International, Cambridge, p.134, 2000.

BLONDEL, J.; FERRY, C.; FROCHOT, B.. La méthode des indices ponctuels d'abundance (IPA) ou des relevés d'avifaune par 'stations d'écoute'. Alauda, v.38, p.55-71, 1970.

BOUTON, S. N.. Ecoturismo nos ninhais de ave pernalta no Pantanal Brasileiro: implicações biológicas e socioeconômicas. Dissertação (Mestrado em Ciências) Universidade da Flórida, Gainesville, 1999.

BRASIL. Ministério do Meio Ambiente/GIZ. Revisão Periódica da Reserva da Biosfera do Pantanal (2000-2015). Reserva da Biosfera do Pantanal. Brasília: MMA, 2015.

CALHEIROS, D. F.; CASTRILON, S. K. I.; BAMPI, A. C. Hidrelétricas nos rios formadores do pantanal: ameaças à conservação e às relações socioambientais e econômicas pantaneiras tradicionais. Revista Ibero-Americana de Ciências Ambientais, v.9, n.1, p.119-139, 2018. DOI: http://doi.org/10.6008/CBPC2179-6858.2018.001.0009

COLLAR, N. J.. Family Psittacidae (Parrots). In: DEL HOYO, J; ELLIOT, A.; SAGARTAL, J.. Handbook of the Birds of the World. Sandgrouse to Cuckoos. Barcelona: Lynx Edicions, 1997.

COLWELL, R. K.. Estimates: Statistical estimation of species richness and shared species from samples. 2013.

CONNOR, K. J.; GABOR, S.. Breeding waterbird wetland habitat availability and response to water-level management in Saint John River floodplain wetlands, New Brunswick. Hydrobiologia, v.567, n.1, p.169-181, 2006. 
FAIRBAIRN, S. E.; DINSMORE, J. J.. Local and landscape-level influences on wetland bird communities of the prairie pothole region of lowa, USA. Wetlands, v.21, p.41-47, 2001.

FROTA, A. V. B.; VITORINO, B. D.; SILVA, C. J.; IKEDACASTRILLON, S. K.; NUNES, J. R. S.. Bird community structure in macrohabitats of the aquatic-terrestrial transition zone in the Pantanal wetland, Brazil. Oecologia Australis, v.24, n.3, p.615-634. 2020a.

FROTA, A. V. B.; VITORINO, B. D.; SILVA, C. J.; IKEDACASTRILLON, S. K.; NUNES, J. R. S.. Birds of the Ramsar site Estação Ecológica de Taiamã and buffer zone, Pantanal wetlands, Brazil. Check List, v.16, n.2, p.401-422, 2020 b. DOI: https://doi.org/10.15560/16.2.401

GARDNER, T. A.; BARLOW, J.; PERES, C. A.. Paradox, presumption and pitfalls in conservation biology: The importance of habitat change for amphibians and reptiles. Biological Conservation, v.138, p.166-179, 2007.

GILL, F. B.. Ornithology. 2 ed. New York: W. H. freeman and Company, 1994.

GUIMARAES, M. R.; LOPES, E. V.; LOURDES-RIBEIRO, A.; MENDONÇA, L. B.; ANJOS, L.. Aves da planície alagável do alto rio Paraná-Maringá. Eduem, 2007.

HARRIS, M. B.; MOURAO, G.; TOMAS, W.; SILVA, C. J.; SONODA, F.; FACHIN, E.; GUIMARÃES, E.. Safeguarding the Pantanal Wetlands: Threats and Conservation Initiatives. Conservation Biology, Washington, v.19, n.3, p.714-720, 2005.

HARTMAN, F. A.. Locomotor mechanisms of birds. Smithsonian Miscelaneous Collection, n.143, p.1-91, 1961.

HERZOG, S. K.; KESSLER, M.. Biogeography and composition of dry forest bird communities in Bolivia. Journal of Ornithology, v.144, p.171-204, 2002.

HOLMES, R. T.. Food resource availability and use in forest bird communities: a comparative view and critique. In: KEAST, A.. Biogeography and ecology of forest bird communities. The Hague: SPB Academic Publishing, 1990. p.387-393.

JUNK, W. J.; BAYLEY, P. B.; SPARKS, R. E.. The flood pulse concept in river-floodplain systems. Canadian Journal of Fishers and Aquatic Sciences, v.106, p.110-127, 1989.

JUNK, W. J.; CUNHA, C .N.; WANTZEN, K. M.; PETERMANN, P.; STRÜSSMANN, C.; MARQUES, M. I.; ADIS, J.. Biodiversity and its conservation in the Pantanal of Mato Grosso, Brazil. Aquatic Sciences, v.68, p.278-309, 2006. DOI: https://doi.org/10.1007/s00027-006-0851-4

JUNK, W. J.; SILVA, C. J.. O conceito do pulso de inundação e suas implicações para o Pantanal de Mato Grosso. In: SIMPÓSIO SOBRE RECURSOS NATURAIS E SOCIOECONÔMICOS DO PANTANAL. MANEJO E CONSERVAÇÃO, 2. Anais. Corumbá: EMBRAPA, 2000. p.1728.

KINGSFORD, R. T.; THOMAS, R. F.. Destruction of wetlands and waterbird populations by dams and irrigation on the Murrumbidgee River in Arid Australia. Environmental
Management, v.34, n.3, p.383-396, 2004.

KREBS, C. J.. Ecological methodology. New York: Harper \& Row, 1989.

LÁZARO, W. L.; OLIVEIRA JÚNIOR, E. S.; SILVA, C. J.; CASTRILLON, S. K. I.; MUNIZ, C. C.. Climate change reflected in one of the largest wetlands in the world: An overview of the Northern Pantanal water regime. Acta Limnologica Brasiliensia, v.32, p.1-8, 2020. DOI: http://doi.org/10.1590/s2179-975x7619

LOPES, I. F.. Variabilidade genética em populações de Jabiru mycteria (Lichtenstein, 1819) e Mycteria americana (Linneaus, 1758) (Aves, Ciconiidae): fluxo gênico e filogeografia. São Carlos: UFSCar, 2006.

MAGURRAN, A. E.. Measuring biological diversity. Oxford: Blackwell Publishing Company, 2004.

MARINI, M. A.; GARCIA, F. I.. Conservação de aves no Brasil. Megadiversidade, v.1, n.1, p.95-102, 2005.

MARTÍNEZ-VILALTA, A.; MOTIS, A.. Family ardeidae. In: DEL HOYO, J.; ELLIOT, A.; SARGATAL, J.. Handbook of the birds of the world. Barcelona: Lynx Edicions, 1992. p.376-429.

MITCHELL, W. A.. Species profile: Wood Stork (Mycteria americana) on military installations in the southeastern United States. Technical Report SERDP-99-2. Vicksburg: U.S. Army Engineer Research and Development Center, 1999.

MITSCH, W. J.; BERNAL, B.; HERNANDEZ, M. E.. Ecosystem services of wetlands. International Journal of Biodiversity Science, Ecosystem Services \& Management, v.11, p.1, p.14, 2015.

NUNES, A. P.. Quantas espécies de aves ocorrem no Pantanal brasileiro?. Atualidades Ornitológicas, v.160, p.4554, 2011.

NUNES, A. P.; TOMAS, W. M.. Aves migratórias ocorrentes no Pantanal: Caracterização e Conservação. Corumbá: EMBRAPA, 2004.

OGDEN, J. C.. Checklist of birds: everglades national park. Miami: Everglades Natural History Association, 1969.

OGDEN, J. C.; KUSHLAN, J. A.; TILMANT, J. T.. The food habits and nesting success of Wood Storks in Everglades National Park in 1974. National Park Service. Natural Resources Report, n.16, 1978.

OKSANEN, J.; BLANCHET, F. G.; FRIENDLY, M.; KINDT, R.; LEGENDRE, P.; MCGLIN, D; O'HARA, R. B.; SIMPSON, G. L; SOLYMOS, P.; STEVENS, M. H. H.; SZOECS, E; WAGNER, H.. Vegan: Community Ecology Package. 2019.

OLIVEIRA, M. M. A.. Aves e vegetação em um bairro residencial da cidade de São Paulo (São Paulo, Brasil). Revista Brasileira de Zoologia, v.12, p.81-92, 1995.

OLIVEIRA, A. C.; BARBOSA, A. E. A.; SOUSA, A. E. B. A.; LUGARINI, C.; LIMA, D. M.; NASCIMENTO J. L. X.; SOUZA, M. A. SOMENZARI, M.; SOUZA, N. A.; SERAFINI, P. P.; AMARAL, P. P.; ROSSATO, R. M.; MEDEIROS, R. C. S.. Relatório anual de rotas e áreas de concentração de aves migratórias no 
Brasil. Cabedelo: CEMAVE/ICMBio, 2016.

PETRY, M. V.; SCHERER, J. F. M.. Distribuição da avifauna em um gradiente do Rio dos Sinos, São Leopoldo, Rio Grande do Sul, Brasil. Biodiversidade Pampeana, v.6, n.2, p.19-29, 2008.

PIACENTINI, V. Q.; A. ALEIXO, C. E.; AGNE, G. N.; MAURICIO, J. F.; PACHECO, G. A.; BRAVO, G. R. R.; BRITO, L. N.; NAKA, F.; OLMOS, S.; POSSO, L. F.; SILVEIRA, G. S.; BETINI, E.; CARRANO, I.; FRANZ, A. C.; LEES, L. M.; LIMA, D.; PIOLI, F.; SCHUNCK, F. R.; AMARAL, G. A.; BENCKE, M.; COHN-HAFT, L. F. A.; FIGUEIREDO, F. C.; STRAUBE-CESARI, E.. Annotated checklist of the birds of Brazil by the Brazilian Ornithological Records Committee/Lista comentada das aves do Brasil pelo Comitê Brasileiro de Registros Ornitológicos. Revista Brasileira Ornitologia, v.23, n.2, p.91-298, 2015.

PIELOU, E. C.. Ecological diversity. Nova York: Wiley, 1975.

PRIMACK, R. B. E; RODRIGUES, E.. Biologia da Conservação. Londrina: Rodrigues, 2002.

R CORE TEAM. R: A language and environment for statistical computing. Vienna: R Foundation for Statistical Computing, 2019.

RODRIGUES, M.; MICHELIN, V.. Riqueza e diversidade de aves aquáticas de uma lagoa natural no sudeste do Brasil. Rev. Bras. Zool., v.22, n.4, p.928-935, 2005.

RUSSELL, G. J.; DIMOND, J. M.; REED, T.; PIMM, S. L.. Breeding birds on small islands: island biogeography or optimal foraging?. Journal of Animal Ecology, v.75, n.2, p.324-339, 2006. DOI: http://doi.org/10.1111/j.13652656.2006.01052.x

SCHULZ, C.; MARTIN-ORTEGA, J.; IORIS, A. A. R.; GLENK, K.. Applying a 'Value Landscapes Approach' to conflicts in water governance: the case of the Paraguay-Paraná Waterway Ecol. Econ., v.138, p.47-55, 2017.

https://doi.org/10.1016/i.ecolecon.2017.03.033

SICK, H.. Ornitologia Brasileira. Rio de Janeiro: Nova Fronteira, 1997.

SILVA, C. J.; SOUSA, K. N. S.; IKEDA-CASTRILLON, S. K.; LOPES C. R. A. S.; NUNES, J. R. S.; CARNIELLO, M. C.; MARIOTTI, P. R.; LAZARO, W. L.; MORINI, A.; ZAGO, B. W.; FAÇANHA, C. L.; ALBERNAZ-SILVEIRA, R.; LOUREIRO, E.; VIANA, I. G.; OLIVEIRA, R. F.; CRUZ, W. J. A.; ARRUDA, J. C.; SANDER, N. L.; FREITAS JUNIOR, D. S.; PINTO, V. R.; LIMA, A. C.; JONGMAN, R. H. G.. Biodiversity and its drivers and pressures of change in the wetlands of the Upper Paraguay-Guapore Ecotone, Mato Grosso (Brazil). Land Use Policy, v.47, p.163-178, 2015. DOI: https://doi.org/10.1016/j.landusepol.2015.04.004

SILVA, C. J.; ABDO, M. S. A.; OLIVEIRA, D. M. M.; GIRARD, P.. Caraterização Ambiental do ninhal corutuba, Pantanal de Barão de Melgaço, MT. In: SIMPÓSIO SOBRE RECURSOS NATURAIS E SOCIOECONÔMICOS DO PANTANAL: OS DESAFIOS DO NOVO MILÊNIO, 2. Anais. Corumbá, 2000.

SILVA, C. J.; ESTEVES, F. A.. Dinâmica das características limnológicas das Lagoas Porto de Fora e Acurizal em função da variação do nível da água. Oecologia Brasiliensis, v.1, p.47-60, 2005.
SIGRIST, T.. Aves do Brasil: Uma visão artística. São Paulo: Tomas Sigrist, 2006.

THOMAS, K. P. C. S.; BUENO, E. D.; TEIXIDO, A. L.; PINHO, J. B.. Seasonality determines bird abundance, richness, and diversity among contrasting forest environments in the Northern Pantanal. Ornithol. Res., v.28, n.1, p.51-56, 2020. https://doi.org/10.1007/s43388-020-00006-1

TOMAS, W. M.; ROQUE, F. O.; MORATO, R. G.; MÉDICI, P. E.; CHIARAVALLOTI, R. M.; TORTATO, F. R.; PENHA, J. M. F.; IZZO, T. J.; GARCIA, L. C.; LOURIVAL, R. F. F.; GIRARD, P.; LBUQUERQUE, N. R.; ALMEIDA-GOMES, M.; ANDRADE, M. H. S.; ARAÚJO, F. A. S.; ARAÚJO, A. C.; ARRUDA, E. C.; ASSUNÇÃO, V. A.; BATTIROLA, L. D.; BENITES, M.; BOLZAN, F. P.; BOOCK, J. C.; BORTOLOTTO, I. M.; BRASIL, M. S.; CAMILO, A. R.; CAMPOS, Z.; CARNIELLO, M. A.; CATELLA, A. C.; CHEIDA, C. C.; CRAWSHAW JUNIOR. P. G.; CRISPIM, S. M. A.; DAMASCENO JUNIOR, G. A.; DESBIEZ, A. L. J.; DIAS, F. A.; EATON, D. P.; FAGGIONI, G. P.; FARINACCIO, M. A.; FERNANDES, J. F. A.; FERREIRA, V. L.; FISCHER, E. A.; FRAGOSO, C. E.; FREITAS, G. O.; GALVANI, F.; GARCIA, A. S.; GARCIA, C. M.; GRACIOLLI, G.; GUARIENTO, R. D.; GUEDES, N. M. R.; GUERRA, A.; HERRERA, H. M.; HOOGESTEIJN, R.; IKEDA, S. C.; JULIANO, R. S.; KANTEK, D. L. Z. K.; KEUROGHLIAN, A.; LACERDA, A. C. R.; LACERDA, A. L. R.; LANDEIRO, V. L.; LAPS, R. R.; LAYME, V.; LEIMGRUBER, P.; ROCHA, F. L.; MAMEDE, S.; MARQUES, D. K. S.; MARQUES, M. I.; MATEUS, L. A. F.; MORAES R. N.; MOREIRA, T. A.; MOURAO, G.; NICOLA, R. D.; NOGUEIRA, D. G.; NUNES, A. P.; CUNHA, C. N.; OLIVEIRA, M. D.; OLIVEIRA, M. R.; PAGGI, G. M. PELLEGRIN, A. O.; PEREIRA, G. M. F.; PERES, I. A. H. F. S.; PINHO, J. B.; POTT, A.; PROVETE, D. B.; REIS, V. D. A.; REIS, L. K.; RENAUD, P. C.; RIBEIRO, D. B.; ROSSETTO, O. C.; SABINO, J.; RUMIZ, D.; SALIS, S. M.; SANTANA, D. J.; SANTOS, S. A.; SARTORI, Â. L.; SATO, M.; SCHUCHMANN, K.-L.; SCREMINDIAS, E.; SEIXAS, G. H. F.; SEVERO NETO, F.; SIGRIST, M. R.; SILVA, A.; SILVA, C. J.; SIQUEIRA, A. L.; SORIANO, B. M. A.; SOUSA, L. M.; SOUZA, F. L.; STRUSSMANN, C.; SUGAI, L. S. M.; TOCANTINS, N.; URBANETZ, C.; VALENTE-NETO, F.; VIANA, D. P.; YANOSKY, A.; JUNK, W. J.. Sustainability Agenda for the Pantanal Wetland: Perspectives on a collaborative interface for science, policy, and decisionmaking. Tropical Conservation Science, v.12, p.1-30, 2019. DOI: http://doi.org/10.1177/1940082919872634

TRAYLOR, M. A.; FITZPATRICK, J. W.. A survey of tyrant flycatchers. Living bird, New York, v.19, p.750, 1991.

TUBELIS, D. P..; TOMÁS, W. M.. Bird species of the Pantanal wetland, Brazil. Ararajuba, v.11, p.5-37, 2003.

U. S. FISH AND WILDLIFE SERVICE. A newsletter dedicated to sharing information about the wood stork. Wood Stork Report, n.3, p.1-22, 2004.

WANTZEN, K. M.; DRAGO, E. E.; SILVA, C. J.. Aquatic habitats of the upper Paraguay river-floodplain-system and parts of the Pantanal (Brazil). Ecohydrology \& Hydrobiology, v.6, n.2, p.107-126, 2005.

WANTZEN, M.; SILVA, C. J.; FIGUEIREDO, D. M.; MIGLIACIO, $M$. C.. Recent impacts of navigation on the upper Paraguai River. Revista Boliviana de Ecologia y Conservación Ambiental, La Paz, v.6, p.173-182, 1999. 
WI. Wetlands International. Intención Estratégica 2005-

2014. Wageningen: Wetlands International, 2005.

WHITTAKER, R. H.. Dominance and Diversity in Land Plant Communities: Numerical relations of species express the importance of competition in community function and evolution. Science, v.147, p.250-260, 1965.

WINEMILLER, K. O.; TARIM, S.; SHORMANN, D.; COTNER, J. B.. Fish assembleg structure in relation to environmental variation among Brazos River oxbow lakes. Transaction of the American Fisheries Society, v.129, p.451-468, 2000.
WINKLER, D. W.; BILLERMAN, S. M.; LOVETTE, I. J.

Storks (Ciconiidae), version 1.0. In: BILLERMAN, S. M.;

KEENEY, B. K.; RODEWALD, P. G.; SCHULENBERG, T. S.. Birds of the World. Ithaca: Cornell Lab of Ornithology, 2020.

WRI. World Resources Institute. Ecosystems and human well-being: biodiversity synthesis. Washington: World Resources Institute, 2005.

YAMASHITA, C.; VALLE, M. P.. Sobre ninhais de aves do Pantanal do Município de Poconé, Mato Grosso, Brasil. Revista Vida Silvestre Neotropical, v.2, n.2, p.59-6, 1990. 